\title{
Does Body Mass Index Affect Soft Tissue Facial Anthropometric Measurements?
}

\author{
¿El Índice de Masa Corporal Afecta las Mediciones Antropométricas Faciales de Tejidos Blandos?
}

Riad Al-Taee'; Aqeel Ibrahim Lazim Al-Saedi' ${ }^{1}$ \& Mohammed Nahidh²

AL-TAEE, R.; AL-SAEDI, A. I. L. \& NAHIDH, M. Does body mass index affect soft tissue facial anthropometric measurements? Int. J. Morphol., 39(2):520-526, 2021.

SUMMARY: This study aims to test the effect of body mass index on certain facial soft tissue measurements. Three hundred Arab Iraqi young adults with different body mass indexes were randomly selected from the population in Basrah city. Different horizontal and vertical soft tissue measurements were obtained using different calipers. Sex differences were verified by an independent sample t-test, while the effect of different body mass index categories was evaluated by one way ANOVA and Tukey tests. Obese males showed significantly higher mean values for weight, nose width, face width, head circumference, and lower facial third length ( $\mathrm{p} \leq 0.001)$. Obese females shared these parameters with obese males in addition to mouth width. Regarding sex differences, nearly all measurements were significantly higher in males than in females. Obese individuals had wider faces, noses and mouths; larger head circumferences and facial indexes; and longer lower facial third lengths. Moreover, they possessed smaller inner canthal widths as well as upper and middle facial thirds in comparison to normal and overweight subjects.

KEY WORDS: Body mass index; Facial soft tissue; Anthropometric measurements.

\section{INTRODUCTION}

One of the main health concerns nowadays is obesity. Its prevalence has increased rapidly worldwide in recent decades. The major causes of this medical issue are the overingestion of foodstuffs, lack of exercise and physical activity, and the role of environmental, hormonal, and genetic factors (Hill \& Peters, 1998).

Obesity is considered a risk factor for many medical problems, including insulin resistance and type II diabetes, cardiovascular disease, stroke, ischemic heart disease, and metabolic syndromes (Yan et al., 2004). Moreover, it may affect systemic bone metabolism, increase the size and density of the bones, and affect craniofacial development by accelerating the skeletal development of the maxilla and mandible (López-Gómez et al., 2016).

Generally, obesity can occur in two forms: primary and secondary. Primary obesity is caused by the inequality between the amount of food and energyconsumed, while secondary obesity is correlated with genetic and endocrine disorders (Ogden et al., 2002).
Body mass index (BMI, the ratio of body weight to squared standing height $\left.\left[\mathrm{kg} / \mathrm{m}^{2}\right]\right)$ is frequently used as a symbol of general adiposity. According to the World Health Organization (World Health Organization, Regional Office for the Western Pacific, 2000), individuals can be classified as underweight $\left(\mathrm{BMI}<18.5 \mathrm{~kg} / \mathrm{m}^{2}\right)$, normal range $\left(\mathrm{BMI}=18.5-24.9 \mathrm{~kg} / \mathrm{m}^{2}\right)$, overweight or pre-obese $(\mathrm{BMI}=25-$ $29.9 \mathrm{~kg} / \mathrm{m}^{2}$ ), and obese $\left(\mathrm{BMI} \geq 30 \mathrm{~kg} / \mathrm{m}^{2}\right.$ ) (World Health Organization, 2000).

Facial soft tissue is influenced by sex, age, ethnicity, and nutritional status (Simpson \& Henneberg, 2002). BMI is considered as a major aspect affecting facial soft tissue thickness (Fourie et al., 2010).

Many methods have been developed to analyze facial soft tissues, including cephalometric radiography, ultrasonography, MRI, CT scan, and CBCT (Fourie et al.). However,the assessment of facial soft tissues using anthropometric measurements is considered an imperative low-cost method to use during the primary evaluation of an

\footnotetext{
${ }^{1}$ College of Dentistry, University of Basrah, Iraq.

${ }^{2}$ Department of Orthodontics, College of Dentistry, University of Baghdad, Iraq.
} 
individual's nutritional stage and general well-being (de Onis \& Habicht, 1996; Mei et al., 2002).

Most anthropometric studies have concluded that measurements may not be applied for two groups of subjects of different ages and ethnic groups. It has been shown that human faces vary according to ethnicity, age, and BMI (Farkas et al., 2005).

Orthodontists and maxillofacial surgeons should consider differences in ethnicity, BMI, and age in addition to dental and skeletal relationships when assessing orthodontic or orthognathic surgery cases. The aim of the present study is to assess the effect of BMI on certain facial soft tissue measurementsin a sample of Iraqi young adults.

\section{MATERIAL AND METHOD}

Subjects. Approval for this study was gained from the ethical and scientific committee at the College of Dentistry, University of Basrah with the reference number 12-2019.

About 500 individuals agreed to participate in this study, and they were initially examined to fulfill the inclusion criteria. Only 300 individuals were selected and signed the participation consent form. The inclusion criteria for the sample selection were subjects who:

- Were ethnically Arab,

- Were aged between 18 and 28 years old, and

- Had no obvious facial deformities or surgeries, histories of trauma, or congenital and chronic diseases that may affect their craniofacial morphology.

\section{Anthropometric instruments}

1. Medical scale (Detecto, Iwfyan, China) for measuring weight.

2. Anthropomtere (Anthropomtere A-226, Trystom, Czech Republic) for measuring height.

3. Digital sliding caliper (RND 555-00167, RND Lab, China) for measuring inner canthal distance, mouth and nose widths, interparietal width and facial thirds.

4. Spreading calipers (spreading caliper K-211, Trystom, Czech Republic) for measuring facial width.

5. Measuring tape (Galaxy Informatics, India) for measuring head circumference.

Height and weight were first measured to determine BMI. Head circumference was assessed using a special measuring tape above the level of the eye brows and ears and around the back of the head. After that, the facial landmarks were determined using an indelible pencil, and measurements were taken with the head oriented so that the Frankfort plane was parallel to the floor. Minimal pressure was applied to the soft tissue during the measurements using specific calipers. The following landmarks and measurements were determined (Farkas et al.):

\section{A. Landmarks}

1. Trichion $\left(T^{\prime}\right)$ : A point located at the hair line of the forehead.

2. Glabella $\left(G^{\prime}\right)$ : The most prominent midline point between the eyebrows.

3. Euryons (Eu'): Two opposite point on the side of the head (parietal region).

4. Inner canthus of the eye (Ic'): It is the medial angle of palpebral fissure.

5. Zygion (Zyg'): The most lateral point of the soft tissue overlying the zygomatic arch.

6. Alare of the nose $\left(\mathrm{Al}^{\prime}\right)$ : The point that located at each lateral rim of the ala of the nose at its widest width.

7. Subnasale (Sn'): The point at which the nasal columella merges with upper mucocutaneous lip in the mid sagittal plane.

8. Cheilion ( $\left.\mathrm{Ch}^{\prime}\right)$ : A point located at each angle of the mouth.

9. Gnathion $\left(\mathrm{Gn}^{\prime}\right)$ : The midpoint between points soft tissue pogonion and menton.

\section{B. Measurements}

1. Weight: The amount or quantity of person mass $(\mathrm{Kg})$.

2. Height: The distance between the lowest and highest points of a person standing upright $(\mathrm{cm})$.

3. BMI: The ratio of body weight to squared standing height $\left(\mathrm{kg} / \mathrm{m}^{2}\right)$.

4. Head circumference: The largest area around the human's head measured from above the eyebrows and ears around the back of the head.

5. Inter-parietal width: The maximum width at the parietal region from $\mathrm{Eu}^{\prime}$ to $\mathrm{Eu}$ '.

6. Inner-canthal distance: The distance between points Ic' to Ic'.

7. Face width: The distance between the two zygion points.

8. Nose width: The maximum width of the nose from $\mathrm{Al}^{\prime}$ to $\mathrm{Al}^{\prime}$.

9. Mouth width: The distance between points $\mathrm{Ch}^{\prime}$ to $\mathrm{Ch}^{\prime}$.

10. Upper facial third length: The distance between points $T^{\prime \prime}$ and $\mathrm{G}^{\prime}$.

11. Mid facial third length: The distance between points G' and Sn'.

12. Lower facial third length: The distance between point Sn' and $\mathrm{Gn}$ '.

13. Facial index: The proportion of facial width to the sum of mid and lower facial heights.

Statistical analysis. The data were analyzed using SPSS Statistics version 25. Descriptive statistics are presented using means, standard deviations, and minimum and maximum values. Sex differences were tested using an independent sample t-test, and comparisons among different BMI categories were done using a one-way ANOVA test followed by a post hoc Tukey HSD test. The intra- and interobserver reliabilities were tested using an intra-class correlation coefficient (ICC) test. 


\section{RESULTS}

Inter-examiner reliability was assessed with a welltrained orthodontist for all measurements, and the result of the ICC test indicated excellent reliability (0.92). The same

Table I. Distribution of the sample according to the BMI.

\begin{tabular}{ccccc}
\hline Symbol & \multicolumn{2}{c}{ BMI } & Males & Females \\
\hline 0 & Under & $<18.5$ & 5 & 5 \\
I & Normal & $18.5-24.9$ & 82 & 68 \\
II & Over & $25-29.9$ & 43 & 43 \\
III & Obese & $>30$ & 20 & 34 \\
& Total & & 150 & 150 \\
\hline
\end{tabular}

variables were measured again by the same operator after two weeks on 10 subjects, and the findings of the ICC test indicated excellent reliability once again (0.95).

The BMI distribution of the collected sample is presented in Table I. The smallest category is that of underweight individuals, so they were excluded from the research for statistical reasons. The largest subsample had a normal BMI followed by the overweight and the obese.

Tables II and III showed the descriptive statistics and comparison of the BMI categories in the male and female groups, respectively. Generally, obese individuals had the highest mean values for all measured parameters with

Table II. Descriptive statistics and groups' difference for the measured variables in different BMI males.

\begin{tabular}{|c|c|c|c|c|c|c|c|c|c|c|}
\hline \multirow{3}{*}{ Parameters } & \multirow{3}{*}{ Groups } & \multirow{2}{*}{\multicolumn{5}{|c|}{ Descriptive statistics }} & \multicolumn{4}{|c|}{ Groups' difference } \\
\hline & & & & & & & \multicolumn{2}{|c|}{ ANOVA } & \multicolumn{2}{|c|}{ Tukey HSD } \\
\hline & & $\mathrm{N}$ & Mean & \multirow{2}{*}{$\begin{array}{l}\text { S.D. } \\
7.520\end{array}$} & Min. & Max. & $\mathrm{F}$-test & p-value & Groups & p-value \\
\hline & I & 82 & 66.890 & & 54 & 85 & & & I-II & 0.000 \\
\hline \multirow[t]{3}{*}{ Weight (kg) } & II & 43 & 82.442 & 8.186 & 66 & 100 & 159.738 & 0.000 & I-III & 0.000 \\
\hline & III & 20 & 98.950 & 7.626 & 89 & 116 & & & II-III & 0.000 \\
\hline & $\mathrm{I}$ & 82 & 173.488 & 6.623 & 160 & 190 & & & & \\
\hline \multirow[t]{3}{*}{ Height (cm) } & II & 43 & 172.372 & 7.368 & 155 & 190 & 0.426 & 0.654 & & \\
\hline & III & 20 & 172.550 & 6.871 & 160 & 188 & & & & \\
\hline & I & 82 & 3.241 & 0.247 & 2.5 & 4 & & & & \\
\hline \multirow[t]{3}{*}{ Inner-canthal distance $(\mathrm{cm})$} & II & 43 & 3.300 & 0.206 & 2.9 & 3.7 & 1.354 & 0.261 & & \\
\hline & III & 20 & 3.315 & 0.218 & 3 & 3.9 & & & & \\
\hline & I & 82 & 3.608 & 0.284 & 3 & 4.2 & & & $\mathrm{I}-\mathrm{II}$ & 0.233 \\
\hline \multirow[t]{3}{*}{ Nose width $(\mathrm{cm})$} & II & 43 & 3.702 & 0.332 & 3 & 4.5 & 4.826 & 0.009 & I-III & 0.010 \\
\hline & III & 20 & 3.835 & 0.336 & 3.2 & 4.4 & & & II-III & 0.248 \\
\hline & $\mathrm{I}$ & 82 & 4.904 & 0.389 & 4 & 5.8 & & & & \\
\hline \multirow[t]{3}{*}{ Mouth width $(\mathrm{cm})$} & II & 43 & 4.928 & 0.376 & 4 & 5.8 & 0.122 & 0.885 & & \\
\hline & III & 20 & 4.945 & 0.349 & 4 & 5.5 & & & & \\
\hline & I & 82 & 10.007 & 0.570 & 8 & 11.5 & & & I-II & 0.270 \\
\hline \multirow[t]{3}{*}{ Face width $(\mathrm{cm})$} & II & 43 & 10.181 & 0.621 & 9.1 & 11.5 & 6.084 & 0.003 & I-III & 0.002 \\
\hline & III & 20 & 10.515 & 0.642 & 9.4 & 11.8 & & & II-III & 0.100 \\
\hline & $\mathrm{I}$ & 82 & 17.622 & 1.050 & 12 & 20 & & & & \\
\hline \multirow[t]{3}{*}{ Inter-parietal width $(\mathrm{cm})$} & II & 43 & 17.674 & 1.040 & 15 & 20 & 1.805 & 0.168 & & \\
\hline & III & 20 & 18.100 & 0.788 & 17 & 19 & & & & \\
\hline & I & 82 & 56.707 & 1.703 & 53 & 63 & & & I-II & 0.848 \\
\hline \multirow[t]{3}{*}{ Head circumference $(\mathrm{cm})$} & II & 43 & 56.884 & 1.735 & 53 & 60 & 3.595 & 0.030 & I-III & 0.022 \\
\hline & III & 20 & 57.850 & 1.694 & 54 & 62 & & & II-III & 0.096 \\
\hline & I & 82 & 5.691 & 0.683 & 3.8 & 7.9 & & & & \\
\hline \multirow[t]{3}{*}{ Upper third length $(\mathrm{cm})$} & II & 43 & 5.777 & 0.716 & 4.2 & 7 & 0.466 & 0.628 & & \\
\hline & III & 20 & 5.585 & 1.035 & 3.9 & 7.5 & & & & \\
\hline & I & 82 & 5.811 & 0.515 & 4.8 & 7.1 & & & & \\
\hline \multirow[t]{3}{*}{ Mid third length (cm) } & II & 43 & 5.900 & 0.474 & 4.9 & 6.7 & 0.982 & 0.377 & & \\
\hline & III & 20 & 5.715 & 0.525 & 4.8 & 6.6 & & & & \\
\hline & I & 82 & 5.928 & 0.503 & 4.8 & 7.3 & & & I-II & 0.207 \\
\hline \multirow[t]{3}{*}{ Lower third length $(\mathrm{cm})$} & II & 43 & 6.084 & 0.485 & 5 & 7.3 & 3.281 & 0.040 & I-III & 0.049 \\
\hline & III & 20 & 6.205 & 0.399 & 5.6 & 7.1 & & & II-III & 0.626 \\
\hline & I & 82 & 0.857 & 0.079 & 0.645 & 1.042 & & & & \\
\hline \multirow[t]{2}{*}{ Facial index } & II & 43 & 0.853 & 0.073 & 0.720 & 1.058 & 1.381 & 0.255 & & \\
\hline & III & 20 & 0.887 & 0.099 & 0.772 & 1.135 & & & & \\
\hline
\end{tabular}


significant differences in weight, nose width, face width, head circumference, and lower facial third length. Inner canthal width and upper and middle facial third length were smaller in obese subjects.
The mean \pm standard deviations of the measured variables and sex differences for each BMI category are presented in Table IV. In nearly all BMI categories, males had significantly higher mean values than females.

Table III. Descriptive statistics and groups' difference for the measured variables in different BMI females.

\begin{tabular}{|c|c|c|c|c|c|c|c|c|c|c|}
\hline \multirow{3}{*}{ Parameters } & \multirow{3}{*}{ Groups } & \multirow{2}{*}{\multicolumn{5}{|c|}{ Descriptive statistics }} & \multicolumn{4}{|c|}{ Groups' difference } \\
\hline & & & & & & & \multicolumn{2}{|c|}{ ANOVA } & \multicolumn{2}{|c|}{ Tukey HSD } \\
\hline & & $\mathrm{N}$ & Mean & \multirow{2}{*}{$\frac{\text { S.D. }}{6.148}$} & Min. & Max. & F-test & $\mathrm{p}$-value & Groups & p-value \\
\hline \multirow{3}{*}{ W eight $(\mathrm{kg})$} & I & 68 & 57.213 & & 46 & 74 & & & I-II & 0.000 \\
\hline & II & 43 & 70.186 & 5.997 & 60 & 85 & 176.432 & 0.000 & I-III & 0.000 \\
\hline & III & 34 & 86.500 & 10.880 & 70 & 106 & & & II-III & 0.000 \\
\hline \multirow{3}{*}{ Height $(\mathrm{cm})$} & I & 68 & 159.779 & 5.571 & 150 & 175 & & & & \\
\hline & II & 43 & 160.372 & 5.399 & 146 & 171 & 1.899 & 0.153 & & \\
\hline & III & 34 & 158.029 & 5.090 & 148 & 167 & & & & \\
\hline \multirow{3}{*}{ Inner-canthal distance $(\mathrm{cm})$} & I & 68 & 3.175 & 0.218 & 2.7 & 4 & & & & \\
\hline & II & 43 & 3.212 & 0.203 & 2.8 & 3.6 & 0.365 & 0.695 & & \\
\hline & III & 34 & 3.194 & 0.251 & 2.8 & 3.7 & & & & \\
\hline \multirow{3}{*}{ Nose width $(\mathrm{cm})$} & I & 68 & 3.293 & 0.249 & 2.5 & 4 & & & I-II & 0.099 \\
\hline & II & 43 & 3.405 & 0.288 & 2.7 & 4 & 6.079 & 0.003 & I-III & 0.003 \\
\hline & III & 34 & 3.488 & 0.315 & 3.1 & 4.3 & & & II-III & 0.389 \\
\hline \multirow{3}{*}{ Mouth width (cm) } & I & 68 & 4.497 & 0.339 & 3.9 & 5.5 & & & I-II & 0.008 \\
\hline & II & 43 & 4.723 & 0.399 & 3.9 & 5.5 & 7.453 & 0.001 & I-III & 0.003 \\
\hline & III & 34 & 4.765 & 0.443 & 3.8 & 5.5 & & & II-III & 0.885 \\
\hline \multirow{3}{*}{ Face width $(\mathrm{cm})$} & I & 68 & 9.737 & 0.576 & 8.6 & 11 & & & I-II & 0.038 \\
\hline & II & 43 & 10.033 & 0.671 & 8.8 & 11.5 & 4.824 & 0.009 & I-III & 0.025 \\
\hline & III & 34 & 10.076 & 0.609 & 8.9 & 11.5 & & & II-III & 0.948 \\
\hline \multirow{3}{*}{ Inter-parietal width (cm) } & I & 68 & 16.868 & 0.896 & 15 & 19 & & & & \\
\hline & II & 43 & 17.023 & 1.035 & 15 & 19 & 2.158 & 0.119 & & \\
\hline & III & 34 & 17.294 & 1.060 & 15 & 19 & & & & \\
\hline \multirow{3}{*}{ Head circumference $(\mathrm{cm})$} & I & 68 & 55.103 & 2.103 & 50 & 61 & & & I-II & 0.001 \\
\hline & II & 43 & 56.465 & 1.653 & 51 & 60 & 7.667 & 0.001 & I-III & 0.043 \\
\hline & III & 34 & 56.059 & 1.613 & 53 & 60 & & & II-III & 0.612 \\
\hline \multirow{3}{*}{ Upper third length $(\mathrm{cm})$} & I & 68 & 5.574 & 0.588 & 4 & 7.2 & & & & \\
\hline & II & 43 & 5.688 & 0.551 & 4.5 & 7.1 & 1.847 & 0.161 & & \\
\hline & III & 34 & 5.438 & 0.544 & 4 & 6.4 & & & & \\
\hline \multirow{3}{*}{ Mid third length $(\mathrm{cm})$} & I & 68 & 5.660 & 0.409 & 4.9 & 7 & & & & \\
\hline & II & 43 & 5.688 & 0.389 & 4.9 & 6.5 & 0.446 & 0.641 & & \\
\hline & III & 34 & 5.603 & 0.392 & 4.6 & 6.4 & & & & \\
\hline \multirow{3}{*}{ Lower third length $(\mathrm{cm})$} & I & 68 & 5.682 & 0.355 & 5 & 6.5 & & & I-II & 0.000 \\
\hline & II & 43 & 5.974 & 0.403 & 5.3 & 7.2 & 8.239 & 0.000 & I-III & 0.943 \\
\hline & III & 34 & 5.709 & 0.419 & 5 & 7 & & & II-III & 0.009 \\
\hline \multirow{3}{*}{ Facial Index } & I & 68 & 0.861 & 0.064 & 0.722 & 0.991 & & & & \\
\hline & II & 43 & 0.863 & 0.073 & 0.731 & 1.085 & 2.867 & 0.060 & & \\
\hline & III & 34 & 0.893 & 0.066 & 0.792 & 1.052 & & & & \\
\hline
\end{tabular}

I: Normal BMI, II: Over, III: Obese.

\section{DISCUSSION}

The face, the main visible component of the human body, gives an impression of a person's age, sex, ethnicity, and health. During ontogenesis, the facial features undergo marked changes in size and shape associated mostly with the growth and development of underlying bone structures.
Reference anthropometric data of the face are not merely crucial for the quantitative description of normal individuals, but they could also be valuable in diagnostic procedures to differentiate between pathologies as well as individual morphologic variations (Ward et al., 2000). Based 
Table IV. Descriptive statistics and sex difference for the measured variables in different BMI.

\begin{tabular}{|c|c|c|c|c|c|c|c|}
\hline \multirow{3}{*}{ BMI } & \multirow{3}{*}{ Parameters } & \multicolumn{4}{|c|}{ Des criptive statistics } & \multirow{2}{*}{\multicolumn{2}{|c|}{ Sex difference }} \\
\hline & & \multicolumn{2}{|c|}{ Males } & \multicolumn{2}{|c|}{ Females } & & \\
\hline & & Mean & S.D. & Mean & S.D. & t-test & $\mathrm{p}$-value \\
\hline \multirow{12}{*}{ I } & Weight (kg) & 66.890 & 7.520 & 57.213 & 6.148 & 8.511 & 0.000 \\
\hline & Height $(\mathrm{cm})$ & 173.488 & 6.623 & 159.779 & 5.571 & 13.549 & 0.000 \\
\hline & Inner-canthal distance $(\mathrm{cm})$ & 3.241 & 0.247 & 3.175 & 0.218 & 1.727 & 0.086 \\
\hline & Nose width $(\mathrm{cm})$ & 3.608 & 0.284 & 3.293 & 0.249 & 7.158 & 0.000 \\
\hline & Mouth width (cm) & 4.904 & 0.389 & 4.497 & 0.339 & 6.746 & 0.000 \\
\hline & Face width $(\mathrm{cm})$ & 10.007 & 0.570 & 9.737 & 0.576 & 2.881 & 0.005 \\
\hline & Inter-parietal width $(\mathrm{cm})$ & 17.622 & 1.050 & 16.868 & 0.896 & 4.677 & 0.000 \\
\hline & Head circumference $(\mathrm{cm})$ & 56.707 & 1.703 & 55.103 & 2.103 & 5.163 & 0.000 \\
\hline & Upper third length $(\mathrm{cm})$ & 5.691 & 0.683 & 5.574 & 0.588 & 1.120 & 0.264 \\
\hline & Mid third length (cm) & 5.811 & 0.515 & 5.660 & 0.409 & 1.956 & 0.052 \\
\hline & Lower third length $(\mathrm{cm})$ & 5.928 & 0.503 & 5.682 & 0.355 & 3.387 & 0.001 \\
\hline & Facial index & 0.857 & 0.079 & 0.861 & 0.064 & -0.316 & 0.752 \\
\hline \multirow{12}{*}{ II } & Weight (kg) & 82.442 & 8.186 & 70.186 & 5.997 & 7.920 & 0.000 \\
\hline & Height $(\mathrm{cm})$ & 172.372 & 7.368 & 160.372 & 5.399 & 8.615 & 0.000 \\
\hline & Inner-canthal distance $(\mathrm{cm})$ & 3.300 & 0.206 & 3.212 & 0.203 & 2.006 & 0.048 \\
\hline & Nose width $(\mathrm{cm})$ & 3.702 & 0.332 & 3.405 & 0.288 & 4.442 & 0.000 \\
\hline & Mouth width (cm) & 4.928 & 0.376 & 4.723 & 0.399 & 2.450 & 0.016 \\
\hline & Face width $(\mathrm{cm})$ & 10.181 & 0.621 & 10.033 & 0.671 & 1.068 & 0.289 \\
\hline & Inter-parietal width $(\mathrm{cm})$ & 17.674 & 1.040 & 17.023 & 1.035 & 2.910 & 0.005 \\
\hline & Head circumference $(\mathrm{cm})$ & 56.884 & 1.735 & 56.465 & 1.653 & 1.146 & 0.255 \\
\hline & Upper third length $(\mathrm{cm})$ & 5.777 & 0.716 & 5.688 & 0.551 & 0.641 & 0.523 \\
\hline & Mid third length $(\mathrm{cm})$ & 5.900 & 0.474 & 5.688 & 0.389 & 2.264 & 0.026 \\
\hline & Lower third length $(\mathrm{cm})$ & 6.084 & 0.485 & 5.974 & 0.403 & 1.137 & 0.259 \\
\hline & Facial index & 0.853 & 0.073 & 0.863 & 0.073 & -0.618 & 0.539 \\
\hline \multirow{12}{*}{ III } & Weight (kg) & 98.950 & 7.626 & 86.500 & 10.880 & 4.500 & 0.000 \\
\hline & Height $(\mathrm{cm})$ & 172.550 & 6.871 & 158.029 & 5.090 & 8.877 & 0.000 \\
\hline & Inner-canthal distance $(\mathrm{cm})$ & 3.315 & 0.218 & 3.194 & 0.251 & 1.791 & 0.079 \\
\hline & Nose width $(\mathrm{cm})$ & 3.835 & 0.336 & 3.488 & 0.315 & 3.811 & 0.000 \\
\hline & Mouth width (cm) & 4.945 & 0.349 & 4.765 & 0.443 & 1.556 & 0.126 \\
\hline & Face width $(\mathrm{cm})$ & 10.515 & 0.642 & 10.076 & 0.609 & 2.506 & 0.015 \\
\hline & Inter-parietal width $(\mathrm{cm})$ & 18.100 & 0.788 & 17.294 & 1.060 & 2.950 & 0.005 \\
\hline & Head circumference $(\mathrm{cm})$ & 57.850 & 1.694 & 56.059 & 1.613 & 3.868 & 0.000 \\
\hline & Upper third length $(\mathrm{cm})$ & 5.585 & 1.035 & 5.438 & 0.544 & 0.684 & 0.497 \\
\hline & Mid third length $(\mathrm{cm})$ & 5.715 & 0.525 & 5.603 & 0.392 & 0.893 & 0.376 \\
\hline & Lower third length $(\mathrm{cm})$ & 6.205 & 0.399 & 5.709 & 0.419 & 4.276 & 0.000 \\
\hline & Facial index & 0.887 & 0.099 & 0.893 & 0.066 & -0.257 & 0.798 \\
\hline
\end{tabular}

I: Normal BMI, II: Over, III: Obese.

on Nádaždyová et al. (2016) findings, the difference between direct and digital anthropometric measurements is less than $3 \mathrm{~mm}$. This is considered clinically insignificant, so direct measurements were used in this study.

Healthy young adult subjects aged 18 to 28 years were selected for this study to reduce the effect of growth in the measurements and because this age range most often seeks orthodontic or orthognathic interventions regarding facial esthetics.

It has been reported that obesity causes deleterious effect on health. More specifically, obesity can influence systemic bone metabolism all the way through complex mechanical, hormonal, and inflammatory interactions
(López-Gómez et al.). The size and density of the vertebral bones can increase, and accelerated skeletal development can occur as a result of obesity in childhood and adolescence (Leonard et al., 2004).

Many studies worldwide have been conducted to assess the effect of obesity on craniofacial measurements. Ohrn et al. (2002), Ferrario et al. (2004) and Nádazdyová et al. studied the soft tissue facial morphology of obese subjects. They found that obese subjects had faces that were transversally wider, sagittally deeper, and vertically shorter-especially in upper anterior facial height.

Raza \& Wang (2012) found a non-significant effect of BMI on nasal cavity geometry, while Dong et al. (2012) 
showed that facial soft tissue thickness increased with increasing BMI values in both male and female subjects. Moreover, facial soft tissue thickness changed with individuals' nutritional status, and BMI was considered the main factor in the change of facial soft tissue thickness. Similarly, EftekhariMoghadam et al. (2020) found a significant association between soft tissue thickness MRI measurements and BMI.

Using standard frontal photographs, Windhager et al. (2013) found that fatty young females were characterized by a relatively rounder and larger lower face, smaller eyes, a shorter and wider nose, fuller lips, and downturned corners of the mouth. In contrast, those with low body fat possessed a wider forehead, more angular lower face, a pointier chin, relatively larger eyes, longer noses, wider and thinner lips, and upturned corners of the mouth.

In a longitudinal photographic study, Jandová \& Urbanová (2016) suggested that shape changes in children's faces are characterized by considerable diversity among individuals and are influenced by body proportions and environmental factors, such as living conditions and the mother's smoking habits.

In a cephalometric study conducted by Buyuk et al. (2019), overweight subjects showed larger inter-orbital, maxillary, and nasal cavity width. On the other hand, obese subjects showed larger mastoid mandibular, antegonial, and cranial width.

In the present study, BMI is used for the first time to study its effect on facial soft tissues. Three hundred young adult subjects (150 males and 150 females) were enrolled in this study. Of them, 10 (five males and five females) had BMIs below 18.5 , so they were excluded from the study. The rest of the sample was divided according to BMI into normal weight, overweight, and obese subsamples. Different vertical and horizontal soft tissue facial measurements were assessed using the anthropometric method. This method is low cost, noninvasive, and widely used.

Reviewing Tables II and III in the current study reveals that obese subjects had significantly larger head circumferences and facial and nasal widths than the overweight and normal weight subjects. Other measurements like mouth width (in males), inter-parietal width, and facial index were also larger but not significantly so. Innercanthal width and the upper and middle facial thirds were smaller in contrast to the lower facial third, which was significantly larger in obese subjects, confirming the findings of the aforementioned studies. This can be explained by the fact that these craniofacial parameters are most often placed where facial fat is located.
Regarding sex differences for each BMI category (Table IV), males had significantly higher mean values than females for nearly all measurements, confirming the general rule that males have larger facial dimensions than females.

One of the limitations of this study was that the socioeconomic status of the participants was not detected. Dietary habits, nature, physical activity, and skeletal and dental relationships using 3D measuring approaches and including other Iraqi ethnic groups should be considered in future studies.

\section{CONCLUSIONS}

Obese individuals had wider faces, noses, and mouths; larger head circumferences and facial indexes; and longer lower facial thirds. Moreover, they possessed smaller inner canthal widths and upper and middle facial thirds in comparison to normal and overweight subjects.

BMI should be considered a major part in the evaluation of orthodontic or surgical (orthognathic) cases to support a proper diagnosis of the underlying craniofacial form.

AL-TAEE, R.; AL-SAEDI, A. I. L. \& NAHIDH, M.¿El índice de masa corporal afecta las mediciones antropométricas faciales de tejidos blandos? Int. J. Morphol., 39(2):520-526, 2021.

RESUMEN: Este estudio tuvo como objetivo probar el efecto del índice de masa corporal en determinadas medidas de tejidos blandos faciales. Trescientos adultos jóvenes iraquíes con diferentes índices de masa corporal fueron seleccionados al azar de la población de la ciudad de Basora. Se obtuvieron diferentes medidas de tejidos blandos horizontales y verticales utilizando diferentes calibradores. Las diferencias de sexo se verificaron mediante una prueba t independiente, mientras que el efecto de diferentes categorías de índice de masa corporal se evaluó mediante pruebas ANOVA y Tukey de una vía. Los hombres obesos mostraron valores medios significativamente más altos de peso, el ancho de la nariz, el ancho de la cara, la circunferencia de la cabeza y la longitud del tercio inferior del rostro $(\mathrm{p} \leq 0,001)$. Las mujeres obesas comparten estos parámetros con los machos obesos además del ancho de la cavidad oral. Con respecto a las diferencias de sexo, casi todas las medidas fueron significativamente más altas en hombres que en mujeres. Las personas obesas tenían caras, narices y bocas más anchas; circunferencias más grandes de la cabeza e índices faciales; y longitudes de tercio inferior facial más largas. Además, se observaron anchos cantales mediales más pequeños, así como tercios faciales superior y medio en comparación con sujetos normales y con sobrepeso.

PALABRAS CLAVE: Índice de masa corporal; Tejidos blandos faciales; Medidas antropométricas. 


\section{REFERENCES}

Buyuk, S. K.; Genc, E.; Simsek, H. \& Karaman, A. Analysis of facial soft tissue values and cranial skeletal widths in different body mass index percentile adolescent subjects. Cranio, 37(4):223-30, 2019.

de Onis, M. \& Habicht, J. P. Anthropometric reference data for international use: recommendations from a World Health Organization Expert Committee. Am. J. Clin. Nutr., 64(4):650-8, 1996.

Dong, Y.; Huang, L.; Feng, Z.; Bai, S.; Wu, G. \& Zhao, Y. Influence of sex and body mass index on facial soft tissue thickness measurements of the northern Chinese adult population. Forensic Sci. Int., 222(13):396.e1-7, 2012.

Eftekhari-Moghadam, A. R.; Latifi, S. M.; Nazifi, H. R. \& Rezaian, J. Influence of sex and body mass index on facial soft tissue thickness measurements in an adult population of southwest of Iran. Surg. Radiol. Anat., 42(5):627-33, 2020.

Farkas, L. G.; Katic, M. J.; Forrest, C. R.; Alt, K. W.; Bagic, I.; Baltadjiev, G.; Cunha, E.; Cvicelová, M.; Davies, S.; Erasmus, I.; et al. International anthropometric study of facial morphology in various ethnic groups/ races. J. Craniofac. Surg., 16(4):615-46, 2005.

Ferrario, V. F.; Dellavia, C.; Tartaglia, G. M.; Turci, M. \& Sforza, C. Soft tissue facial morphology in obese adolescents: a three-dimensional noninvasive assessment. Angle Orthod., 74(1):37-42, 2004.

Fourie, Z.; Damstra, J.; Gerrits, P. O. \& Ren, Y. Accuracy and reliability of facial soft tissue depth measurements using cone beam computer tomography. Forensic Sci. Int., 199(1-3):9-14, 2010.

Hill, J. O. \& Peters, J. C. Environmental contributions to the obesity epidemic. Science, 280(5368):1371-4, 1998.

Jandová, M. \& Urbanová, P. The relationship between facial morphology, body measurements and socio-economic factors. Anthropol. Rev., 79(2):181-200, 2016.

Leonard, M. B.; Shults, J.; Wilson, B. A.; Tershakovec, A. M. \& Zemel, B. S. Obesity during childhood and adolescence augments bone mass and bone dimensions. Am. J. Clin. Nutr., 80(2):514-23, 2004.

López-Gómez, J. J.; Pérez Castrillón, J. L. \& de Luis Román, D. A. Impact of obesity on bone metabolism. Endocrinol. Nutr., 63(10):551-9, 2016.

Mei, Z.; Grummer-Strawn, L. M.; Pietrobelli, A.; Goulding, A.; Goran, M. I. \& Dietz, W. H. Validity of body mass index compared with other body-composition screening indexes for the assessment of body fatness in children and adolescents. Am. J. Clin. Nutr., 75(6):978-85, 2002.

Nádazdyová, A.; Stefánková, E. \& Samohl, M. The impact of body mass index on craniofacial parameters. Kontakt, 18(4):e253-7, 2016.

Ogden, C. L.; Flegal, K. M.; Carroll, M. D. \& Johnson, C. L. Prevalence and trends in overweight among US children and adolescents, 19992000. JAMA, 288(14):1728-32, 2002.

Ohrn, K.; Al-Kahlili, B.; Huggare, J.; Forsberg, C. M.; Marcus, C. \& Dahllöf, G. Craniofacial morphology in obese adolescents. Acta Odontol. Scand., 60(4):193-7, 2002.

Raza, M. T. \& Wang, D. Y. Is nasal cavity geometry associated with body mass index, height and weight? Indian J. Otolaryngol. Head Neck Surg., 64(3):266-9, 2012.

Simpson, E. \& Henneberg, M. Variation in soft-tissue thicknesses on the human face and their relation to craniometric dimensions. Am. J. Phys. Anthropol., 118(2):121-33, 2002.

Ward, R. E.; Jamison, P. L. \& Allanson, J. E. Quantitative approach to identifying abnormal variation in the human face exemplified by a study of 278 individuals with five craniofacial syndromes. Am. J. Med. Genet., 91(1):8-17, 2000

Windhager, S.; Patocka, K. \& Schaefer, K. Body fat and facial shape are correlated in female adolescents. Am. J. Human Biol., 25(6):847-50, 2013.

World Health Organization, Regional Office for the Western Pacific. The Asia-Pacific Perspective: Redefining Obesity and its Treatment. Sydney, Health Communications Australia, 2000.
Yan, L. L.; Daviglus, M. L.; Liu, K.; Pirzada, A.; Garside, D. B.; Schiffer, L.; Dyer, A. R. \& Greenland, P. BMI and health-related quality of life in adults 65 years and older. Obes. Res., 12(1):69-76, 2004.

Corresponding author:

Mohammed Nahidh

Department of Orthodontics

College of Dentistry

University of Baghdad

IRAQ

Email:m_nahidh79@yahoo.com

Riad AI-Taee. ORCID: 0000-0002-7342-2285

Aqeel Ibrahim Lazim AI-Saedi. ORCID: 0000-0003-3495-784X Mohammed Nahidh. ORCID: 0000-0003-0155-418X

Received: 28-09-2020

Accepted: $26-11-2020$ 